\title{
Acute toxicty of several esential oils on Daphnia magna (Straus, 1816)
}

\section{Uçucu yağların Daphnia magna (Straus, 1816) üzerine akut toksisitesi}

\author{
Özlem Çakal Arslan* • Hatice Parlak • Meltem Boyacıoğlu • Muhammet Ali Karaaslan
}

Ege University, Faculty of Fisheries, Department of Hydrobiology, 35100 Izmir, Turkey

*Corresponding author: ozlem.cakal@ege.edu.tr

How to cite this paper:

Arslan, Ç.Ö., Parlak, H., Boyacıoğlu, M., Karaaslan, A.M., 2014. Acute toxicty of several esential oils on Daphnia magna (Straus, 1816). Ege J Fish Aqua Sci 31(3): 137-143. doi: 10.12714/egejfas.2014.31.3.04

Özet: Bu çalışmada, beslenme, tıbbi tedavi ve kozmetik endüstrisinde kullanımı söz konusu olan 6 çeşit bitkisel yağın Daphnia magna akut hareketsizlik testi ile etkili konsantrasyoları $\left(\mathrm{EC}_{50}\right)$ belirlenmiştir. Toksisite testlerinde Biberiye, Okaliptüs, Üzüm Çekirdeği, Kekik, Çay Ağacı, Buğday özü yağları test maddesi olarak kullanılışşır. Tüm yağların etki konsantrasyonları karşılaştırıldığında $\left(\mathrm{EC}_{50}\right)$ Kekik yağının diğerlerine göre daha toksik olduğu belirlenmiştir.

Anahtar kelimeler: Uçucu yağlar, Akut toksisite, Daphnia magna, Hareketsizlik testi.

Abstract: In this study, effective concentrations $\left(\mathrm{EC}_{50}\right)$ of six natural essential oils as Rosemary, Eucalyptus, Grape Seed, Thyme, Tea Tree, Wheat Germ Oil. This oils are used in supplement in diet, medical treatments and cosmetics industries. In this study, the aquatic toxicity of the oils were examined by using Daphnia magna acute immobilization test. According to the toxicity tests results, Thyme Oil were found to be more toxic among the other oils when comparing the $\mathrm{EC}_{50}$ values.

Keywords: Essential Oil, Acute toxicity, Daphnia magna, Immobilization test

\section{INTRODUCTION}

In this study, aquatic toxicity of the essential oils as Rosemary oil (RO), TeaTree oil (TTO), Wheat Germ Oil (WGO), Grape seed Oil (GSO), Thyme oil (TO) and Eucalyptus Oil (EO) were tested. Essential oils have been widely used for bactericidal, virucidal, fungicidal, antiparasitical, insecticidal, medicinal and cosmetic applications, especially recently in pharmaceutical, sanitary, cosmetic, and agricultural and food industries. Essential oils are volatile, natural, complex compounds and are formed by aromatic plants as secondary metabolites (Reuveni et al. 1984, Bakkali et al. 2008, Evandri et al. 2005).

Essential oils are extracted from various aromatic plants generally localized in temperate to warm countries like Mediterranean and tropical countries. They are liquid, volatile, limpid and rarely colored, lipid soluble and soluble in organic solvents with a generally lower density than that of water. They can be synthesized by all plant organs, i.e. buds, flowers, leaves, stems, twigs, seeds, fruits, roots, wood. (Bakkali et al. 2008, Miresmailli et al. 2006). Essential oils have been largely employed for their antibacterial, antifungal and insecticidal activities (Özcan and Arslan 2011). At present, approximately 3000 essential oils are known, 300 of which are commercially important especially for the pharmaceutical, agronomic, food, sanitary, cosmetic and perfume industries. Essential oils or some of their components are used in perfumes and make-up products, in sanitary products, in dentistry, in agriculture, as food preservers and additives, in perfumes, creams, soaps, as flavor additives for food, as fragrances for household cleaning products and as industrial solvents and as natural remedies, (Bakkali et al. 2008, Perry et al. 2003). Moreover, essential oils are used in massages as mixtures with vegetal oil or in baths but most frequently in aromatherapy. Some essential oils appear to exhibit particular medicinal properties that have been claimed to cure one or another organ dysfunction or systemic disorder (Silva et al. 2003, Hajhashemi et al. 2003, Perry et al. 2003).

This literature knowledges shows that the essential oils used widely and discharged and accumulated in aquatic environment. The lack of information about the toxicity of these essential oils on aquatic organisms courage we to study and test of their toxicity using Daphnia magna immobilization test. 
Daphnia magna is one of the most important fresh water species widely employed in ecotoxicity testing procedures through the world. Except for fish and more recently algae, chronic and acute tests with $D$. magna are among the most frequently performed standardized studies in aquatic toxicology (OECD 2004). D. magna has been used extensively to determine the toxicity of chemicals, effluents, and water and sediment samples and has been demonstrated to be sensitive to many environmental contaminants (Le Blanc 1980, Parlak et al. 2010). The choice of $D$. magna for use as a standard test species was strongly influenced by the following factors: reproduction is normally parthenogenetic, which allows the maintenance and testing of clones; it can be cultured in the laboratory; it represents the zooplankton community, a major element of the freshwater food chain; as a species of worldwide occurrence, the ecological relevance of the test results is recognized. Daphnids are important invertebrate species in aquatic food webs. Most daphnids are cyclic partheogenetic species capable of both asexual and sexual reproduction. Laboratory cultures of Daphnids are typically maintained in partenogenetic state (Le Blanc 1980, Parlak et al. 2010).

Ecotoxicology can be loosely defined as the effects of pollutants on natural ecosystems. Although data from acute toxicity testing of single animal may be regarded as overly simplistic, they are often the starting point for assessing ecotoxicity (Hammer et al. 2006). Data describing the aquatic ecotoxicity of essential oils are very limited.

In our study, considering the knowledge above, we have attempted to determine the acute toxic effects of RO, TTO, WHO, GSO, TO and EO using D.magna and taking immobilized individual into account. As it is well known the toxicity of chemicals were ranged according to species. Although the toxic effects of six essential oils on some acari and bacteria species examined (Laborda et al. 2013), there are lack of information about the toxic effect on aquatic organisms and Daphnids.

\section{MATERIAL AND METHODS}

We used several essential oils which are Rosemary oil (RO), Tea Tree oil (TTO), Wheat Germ Oil (WGO), Grape seed Oil (GSO), Thyme oil (TO) and Eucalyptus Oil (EO) for tests. Stock solutions were prepared as $10 \mathrm{ppm}$ of all essential oils by dissolving the chemicals with Dimethylsulphoxide (DMSO) (Sigma, Cat. No: 67-68-5). From the stock solutions, five experimental concentrations of five essential oils and four concentration of thyme oil (Table 1) were used by dilutions from stock solutions in order to determine the acute toxicity.

Controls accompanying the experiments consisted of untreated negative controls (Filtered Fresh Water: FFW), solvent control (DMSO: $1 \mathrm{ml} / 10 \mathrm{ml}$ ) and $10^{-4} \mathrm{M} \mathrm{CdCl}_{2}$

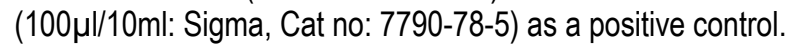

Daphnia magna is one of the most important fresh water species employed in ecotoxicity testing for effluents, water and sediment samples, chemicals and complex mixture (Parlak et al., 2010). D. magna is a species of zooplankton. Due to its worldwide distribution and adaptability to laboratory culture, Daphnia has long been employed as a representative species for testing chemicals (OECD 2004).

The acute toxicity tests were carried out in accordance with the guidelines of the Organization for Economic Cooperation and Development (Test no. 202, Daphnia sp., Acute Immobilization Test) (OECD, 2004). D. magna cultures consisted of glass beakers containing culture medium and 20 daphnids. Culture medium was renewed and offspring produced discarded twice weekly. Brood daphnids were discarded after 4 weeks in culture and replaced with neonatal organisms. Cultures were maintained at $21 \pm 0.5^{\circ} \mathrm{C}$ under 18-h light: 6-h dark photoperiod. The Daphnia were fed $75 \times 106 / \mathrm{ml}$ cells the unicellular green algae Selenastrum copricornutum was cultured in Bristol medium. These culture conditions maintained the daphnids in the parteogenetic reproductive stage.

The primary objective of the 48-hour toxicity test using Daphnia magna. Is to evaluate the acute toxicity of essential oils on freshwater crustaceans. The test is conducted in small beakers or standard test tubes, and often incorporates replication (e.g., 5 organisms in each of 4 replicates). The measurement endpoints generally evaluated are the 48-hour LC 50 (for survival), and the 48-hour $\mathrm{EC}_{50}$ (for immobility). The acute test was performed in accordance to the standard protocol for D. magna immobilization test (OECD 2004). 5 neonates aged less than $24 \mathrm{~h}$, divided in to four groups were exposed to each concentration of essential oils for $48 \mathrm{~h}$ in a static test. The test containers used were $20-\mathrm{ml}$ glass beakers filled with $10 \mathrm{ml}$ of test solution. The test was performed at 20 $\pm 2^{\circ} \mathrm{C}$ under 18 -h light: 6 -h dark photoperiod. Numbers of mobile and immobile specimens were registered after 24 and $48 \mathrm{~h} ; \mathrm{pH}$ and oxygen were measured in the controls and at the highest test concentrations. During the experiments, these physical and chemical variables were measured daily. At the end of the acute toxicity tests, the organisms were observed under a stereomicroscope, and the number of dead neonates in the four replicates was counted and used to determine the 48-h LC50.

The LC50's were calculated by probit analysis using Toxicologist 1.00 (1990) statistical software. All data were tested for statistical significance using a Student-t test.

\section{RESULTS}

Essential oil (RO, TTO, WHO, GSO, EO) bioassay with daphnia 5 concentration was used and 4 concentration was used for TO (Table 1). The summary of 24-h and 48-h acute toxicity of essential oils of 6 essential oils presented in Figures. In this study the $95 \%$ confidence limits overlap and dose-response relationship was defined. 
Concentrations of Thyme oil (TO) were found to be more toxic in the test. The number of Immobilize Daphnids rates was increasing parallel to increasing concentrations in all test medium. In the meantime, any death was found in the control group (Table 2, Figure 3).

Table 1. Concentrations of esential oils.

\begin{tabular}{|l|c|c|c|}
\hline Essential Oils & Physical State and Appearance & Molecular Weight (d) & Concentrations (mg/L) \\
\hline Rosemary Oil (RO) & Liquid & 0.8015 & $4.01,8.02,20.04,48.09,100.19$ \\
\hline Tea Tree Oil (TTO) & Liquid & 0.8043 & $4.02,8.041,12.061,20.1013,40.205$ \\
\hline Wheat Germ Oil (WGO) & Liquid & 0.8057 & $4.03,12.08,20.1,48.3,100.7$ \\
\hline Grape Seed Oil (GSO) & Liquid & 0.7456 & $3.728,11.184,18.64,44.74,93.2$ \\
\hline Thyme Oil (TO) & Liquid & 0.8136 & $3.051,5.085,12.204,54.425$ \\
\hline Eucalyptus Oil (EO) & Liquid & 0.8446 & $22.53,33.78,45.05,56.31,67.57$ \\
\hline
\end{tabular}

Table 2. Acute test results of essential oils.

\begin{tabular}{|c|c|c|c|}
\hline Essential Oil Concentrations mg/L & Total Number of Individual & Number of Immobilization & $\%$ Number of observed Immobilization \\
\hline $\begin{array}{l}\text { Control } \\
\text { Negative (DMSO) } \\
\text { Positive (CdCl2) }\end{array}$ & $\begin{array}{l}20 \\
20 \\
\end{array}$ & $\begin{array}{l}0 \\
0 \\
20 \\
\end{array}$ & $\begin{array}{l}0 \\
0 \\
100 \\
\end{array}$ \\
\hline \multicolumn{4}{|l|}{ Rosemary Oil (RO) } \\
\hline 4.01 & 20 & $4^{*}$ & 20 \\
\hline 8.02 & 20 & $8^{*}$ & 40 \\
\hline 20.04 & 20 & $13^{*}$ & 65 \\
\hline 48.09 & 20 & $17^{*}$ & 85 \\
\hline 100.19 & 20 & $20^{*}$ & 100 \\
\hline \multicolumn{4}{|l|}{ Tea Tree Oil (TTO) } \\
\hline 4.02 & 20 & $2^{*}$ & 10 \\
\hline 8.041 & 20 & $3^{*}$ & 15 \\
\hline 12.061 & 20 & $7^{\star}$ & 35 \\
\hline 20.1013 & 20 & $11^{*}$ & 55 \\
\hline 40.205 & 20 & $15^{*}$ & 75 \\
\hline \multicolumn{4}{|l|}{ Wheat Germ Oil (WGO) } \\
\hline 4.03 & 20 & $7^{*}$ & 35 \\
\hline 12.08 & 20 & $18^{*}$ & 90 \\
\hline 20.1 & 20 & $18^{*}$ & 90 \\
\hline 48.3 & 20 & $20^{*}$ & 100 \\
\hline 100.7 & 20 & $20^{*}$ & 100 \\
\hline \multicolumn{4}{|l|}{ Grape Seed Oil (GSO) } \\
\hline 3.728 & 20 & $3^{*}$ & 55 \\
\hline 11.184 & 20 & $6^{*}$ & 50 \\
\hline 18.64 & 20 & $7^{\star}$ & 60 \\
\hline 44.74 & 20 & $14^{*}$ & 60 \\
\hline 93.2 & 20 & $20^{*}$ & 75 \\
\hline \multicolumn{4}{|l|}{ Thyme Oil (TO) } \\
\hline 3.051 & 20 & $4^{*}$ & 20 \\
\hline 5.085 & 20 & $5^{*}$ & 25 \\
\hline 12.204 & 20 & $11^{*}$ & 55 \\
\hline 54.425 & 20 & $20^{*}$ & 100 \\
\hline \multicolumn{4}{|l|}{ Eucalyptus Oil (EO) } \\
\hline 22.53 & 20 & 0 & 0 \\
\hline 33.78 & 20 & $6^{*}$ & 30 \\
\hline 45.05 & 20 & $11^{*}$ & 55 \\
\hline 56.31 & 20 & $17^{*}$ & 85 \\
\hline 67.57 & 20 & $20^{*}$ & 100 \\
\hline
\end{tabular}

${ }^{*} \mathrm{p}<0.005$ 
Mobilized Daphnids was $100 \%$ in the control group, while in the solvent substance DMSO, which has no toxic effect, it was $100 \%$. Percentage of immobilized daphnids, depending on the toxicant, began to increase from the first concentrations onwards (Figure 1-3), a $20 \%$ increased being observed at the first concentration of $4.01 \mathrm{mg}-\mathrm{RO} / \mathrm{L} \quad(p<0.005)$. At first concentrations of TTO containing $4.02 \mathrm{mg}$-TTO/L percentage of immobilize daphnids observed as 10\% (Table 2, Figure 1).
However immobilized daphnids was not observed at 22.53 $\mathrm{mg}-\mathrm{EO} / \mathrm{L}$, immobilized daphnids was observed as $35 \%$ for WGO (4.03 mg-WGO/L), 15\% for GSO (3.728 $2 \mathrm{mg}-\mathrm{GSO} / \mathrm{L})$ and $20 \%$ for TO $(3.051 \mathrm{mg}-\mathrm{TO} / \mathrm{L})$. The rise in the doseresponse curve continued until the final concentration of $100.19 \mathrm{mg}-\mathrm{RO} / \mathrm{L}, 40.205 \mathrm{mg}-\mathrm{TTO} / \mathrm{L}, 100.7 \mathrm{mg}-\mathrm{WGO} / \mathrm{L}, 93.2$ $\mathrm{mg}-\mathrm{GSO} / \mathrm{L}, 54.425 \mathrm{mg}-\mathrm{TO} / \mathrm{L}$ and $67.57 \mathrm{mg}-\mathrm{EO} / \mathrm{L}$ (Figure 1-3).
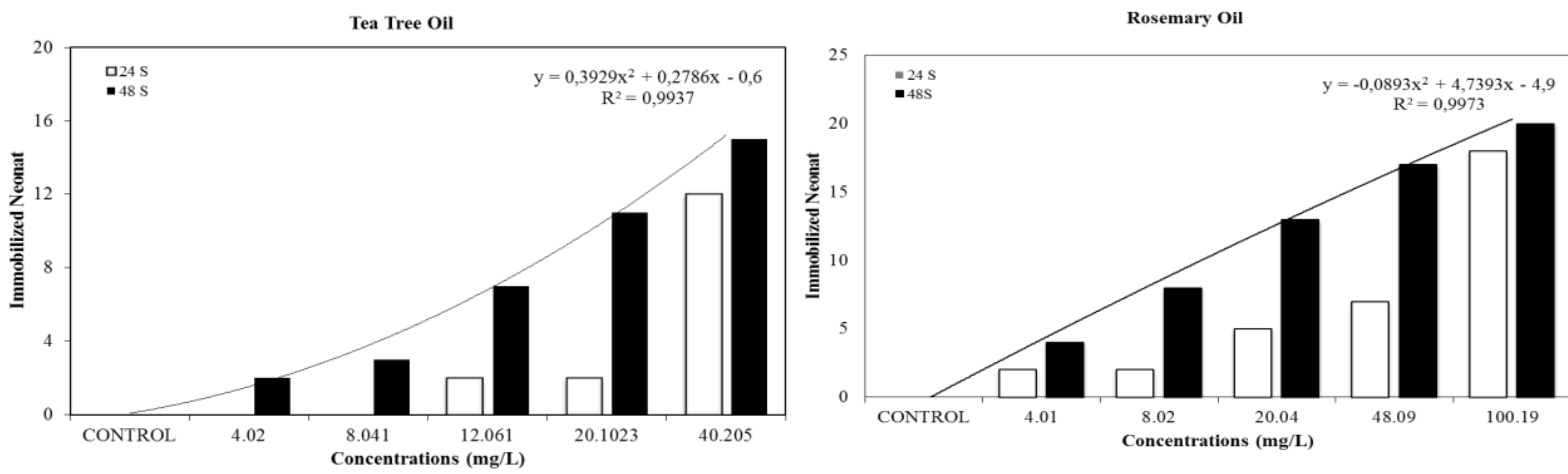

Figure 1. Dose response curve of Rosemary and Tea Tree Oil for immobilized neonate.
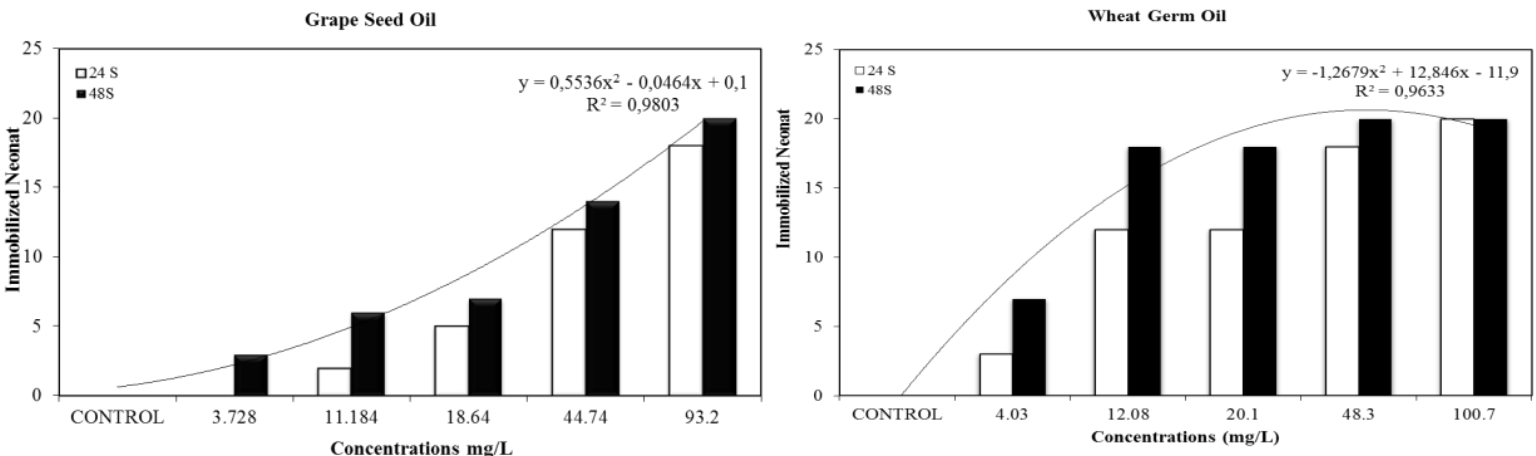

Figure 2. Dose response curve of Wheat Germ and Grape Seed Oil for immobilized neonate.

Eucalyptus Oil

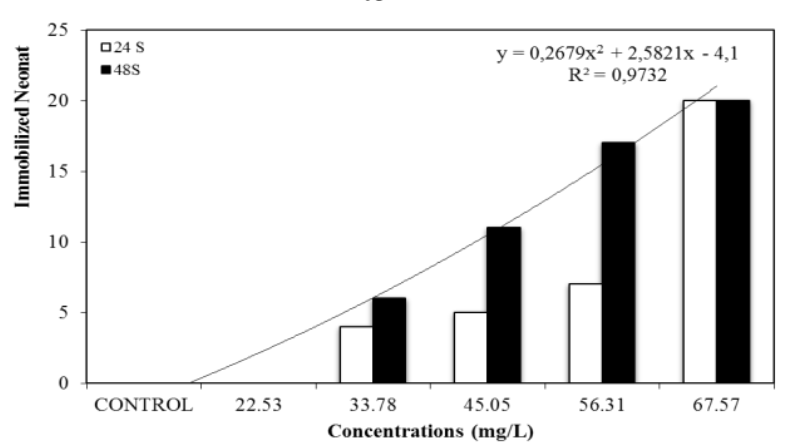

Thyme Oil

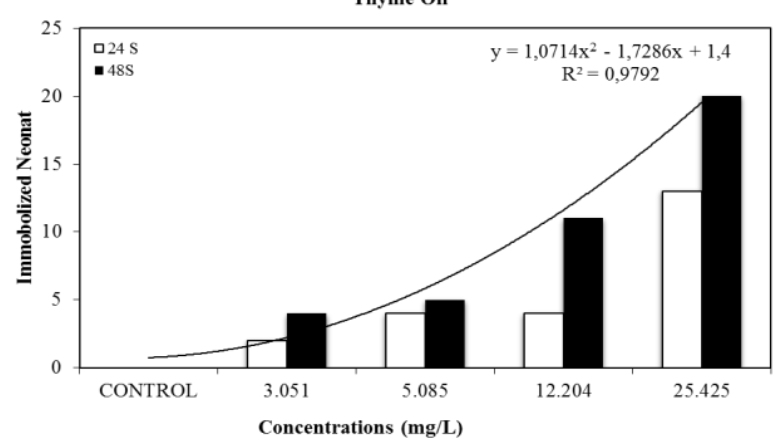

Figure 3. Dose response curve of Thyme and Eucalyptus Oil for Immobilized neonate.

The impact of RO on mobilization of exposed neonate was determined as $\mathrm{EC}_{50} 15.5875 \mathrm{mg} / \mathrm{L} \mathrm{RO}$ concentration by probit analyses Table 3 . The acute toxicity of TTO on mobilization are shown in Table 2. And EC 50 value of TTO was estimated as $18.614 \mathrm{mg} / \mathrm{L}$ (Table 3 ). The $\mathrm{EC}_{50}$ values of other 5 essential oils are shown in Table 3. It can be concluded that comparing $\mathrm{EC}_{50}$ levels of the essential oils concentrations the toxicity order is Eucalyptus Oil< Grape Seed Oil<Tea Tree Oil<Rosemary Oil<Wheat Germ Oil<Thyme Oil (Table 3). 
Table 3. Estimated LC/EC values and confidence limits for immobilized neonate.

\begin{tabular}{|c|c|c|c|c|}
\hline Esential oil & $\begin{array}{l}\text { Exposure } \\
\text { Conc. } \\
\text { (mg/L) }\end{array}$ & \multicolumn{2}{|c|}{$\begin{array}{l}95 \% \text { Confidence } \\
\text { Limits }\end{array}$} & Probit Curve \\
\hline $\begin{array}{l}\text { Rosemary } \\
\text { Oil }\end{array}$ & 15.5875 & 9.965 & 22.775 & $\begin{array}{c}3.7984+1.007 x \\
\log (\text { conc.) }\end{array}$ \\
\hline Tea Tree Oil & 18.614 & 7.937 & 30.144 & $\begin{array}{c}2.490+1.977 x \\
\log (\text { conc. })\end{array}$ \\
\hline $\begin{array}{l}\text { Wheat Germ } \\
\text { Oil }\end{array}$ & 15.059 & $\begin{array}{c}10.66 \\
3\end{array}$ & 20.401 & $\begin{array}{c}2.261+2.326 x \\
\log (\text { conc.) }\end{array}$ \\
\hline $\begin{array}{l}\text { Grape Seed } \\
\text { Oil }\end{array}$ & 23.001 & $\begin{array}{c}12.62 \\
3 \\
\end{array}$ & 55.981 & $\begin{array}{c}2.689+1.697 x \\
\log (\text { conc. })\end{array}$ \\
\hline Thyme Oil & 11.787 & 7.342 & 169.844 & $\begin{array}{c}3.135+1.741 x \\
\log (\text { conc. })\end{array}$ \\
\hline $\begin{array}{l}\text { Eucalyptus } \\
\text { Oil }\end{array}$ & 83.8111 & Too & wide & $\begin{array}{l}2.194+1.459 x \\
\log (\text { conc. })\end{array}$ \\
\hline
\end{tabular}

\section{DISCUSSION}

Essential Oils contain a complex mixture of volatile aroma compounds from secondary plant metabolism. In general antifungal and insecticidal activity of essential oils are well documented (Reuveni et al., 1984). Although researchers describe the in-vivo and in-vitro effects of some essential oil on various animal species. A limited data have been found on the acute toxicity of Rosemary, Tea Tree, Wheat Germ, Greap Seed, Thyme and Eucalyptus Oil, that makes difficult to have comparisons of data's.

However, the acute toxicity of some essential oils to aquatic organism has been assessed by a few researcher (Le Blanc, 1980, Stroh et al,. 1998, Park et al., 2011). The lack of data on the acute toxic effects of essential oils on the physiology, reproduction and development is particularly evident in some aquatic invertebrate taxa, such as Clodoceran. In the study by Pavela (2014), using Culex quinquefasciatus and non-target organism Daphnia magna, in order to determine the acute toxicity of selected essential oil Pimpinella anisum fruits were used. LC50 for instar larvae was estimated as $15-19 \mu / / L$ and besides that essential oil were toxic for D. magna (62-92\% mortality) and significantly reduced fertility. The oil used in this study was not used in our study. But the $D$. magna mortality average were compared our study essential oil we tested are less toxic to $D$. magna.

The essential oil Tea Tree Oil is widely investigated as alternative antimicrobial, anti-inflammatory agent (Hammer et al., 1999, 2006) limited data are available on safety and the toxicity of oil. The mutagenic activity of Tea Tree Oil was determined by Evandri et al., (2005). This researcher reported that essential oils tea tree and lavender have no mutagenic activity either in the TA 98 and TA 100 Salmonella typhimirium. In the study of researcher tea tree oil dilutions were tested $(0.80,0.66,0.50,0.40,0.25$ and $0.13 \mathrm{mg} / \mathrm{plate})$. According to test result of this study tea-tree oil proved toxic on both TA strains (at $0.28 \mathrm{mg} /$ plate on TA98 and at $0.88 \mathrm{mg} / \mathrm{plate}$ on TA100): when the $\mathrm{S} 9$ mixture was added, tea-tree oil was less toxic (toxicity began at $2.78 \mathrm{mg} / \mathrm{plate}$ ).
Although, Tea-tree oil, with and without metabolic activation, induced no antimutagenic activity, on TA98 or TA100. In our study, Tea Tree oil were toxic at $18.614 \mathrm{mg} / \mathrm{L}$. Comparison of The test results of Evandri et al., (2005) and present study showed that strains of Bacteria are more sensitive to Tea Tree oil.

Pimenta et al., (2000) evaluated that acute toxicity of total samples of eucalyptus pyrolysis liquids and the phenolic compounds by $D$. magna bioassay and microtox assay. They are reported that total eucalyptus pyrolysis liquids were immobilize $50 \%$ of the $D$. magna population at concentrations 68- $170 \mathrm{mg} / \mathrm{L}$ and also showed that eucalyptus has no genotoxic effects. In this study, eucalyptus pyrolysis liquids tested while eucalyptus oil were tested in our study. There are no studies with Eucalyptus Oil to determine the effects on aquatic organisms. These results are compared with our study, eucalyptus oil is more toxic than eucalyptus pyrolysis (55\% immobilize Daphnid at 45, $05 \mathrm{mg} / \mathrm{L} ; 50 \%$ at 40,95 $\mathrm{mg} / \mathrm{L})$.

The study of Pavela (2008) were determined the insecticidal activity of 34 essential oils, extracted from plants, was screened against the house fly, Musca domestica L. under laboratory conditions. Results of these study showed that Essential oils from Pogostemon cablin (Patchouili) proved to be the most efficient at a lethal dose of $3 \mu \mathrm{g} / \mathrm{fly}$ after topical application. Eight oils (Pelargonium roseum, Origanum vulgare, Origanum compactum, Mentha pulegium, Ocicum basilicum, Origanum majorana, Thymus vulgaris and Palergonium graveolens) were lethal in doses ranging from 10 to $20 \mu \mathrm{g}$ ( $\mu \mathrm{g} / f \mathrm{ly}$, respectively). The lethal doses of another 13 oils were ascertained in the range (including Rosmerinus officinalis) $20-50 \mu \mathrm{g} / \mathrm{fly}$, nine oils had lethal doses of $50-100$ $\mu \mathrm{g}$. Results of these study showed that Thyme Oil and Rosemary Oil more toxic to house fly Musca domestica L. When comparing these results with our study similar effects were observed according to lethal concentrations.

Khater et al. (2011) using Lucilla sericata (Diptera) exposed essential oils lettuce, chamomile, rosemary and annise, at larval stage it was reported that lethal concentrations (LC50) of $0.57 \%, 0.85 \%, 2.74 \%$, and $6.77 \%$ for lettuce, chamomile, anise, and rosemary oils, respectively. The Study by Seo et al., (2012) were evaluated larvicidial activity of 20 plant essential oils and also tested the acute toxicity of five of these oils. According to their results, Peru balsam, ajowan balsam, benzyl benzoate and thymol were more toxic to $D$. magna. And also reported $L C_{50}$ value as 5.94 $\mathrm{mg} / \mathrm{L}$ for thymol, $3.89 \mathrm{mg} / \mathrm{L}$ for Peru balsam. Although in our study $L C$ 50 value measured as $11,787 \mathrm{mg} / \mathrm{L}$ for Thyme oil. The acute toxicity of some Myrtaceae plant essential oils or their components to aquatic organisms has been assessed. Tea Tree Oil and Eucalyptus oils were classified as nontoxic (EC50 > $10 \mathrm{mg} / \mathrm{L}$ ) (Stroh et al,. 1998, Park et al., 2011). Duringer et al., (2010) were evaluated acute aquatic toxicity of two essential oils (Western juniper and Port orford) using Daphnia magna, Oncorhynchus mykiss and Selenastrum 
copricornutum in order to gauge the relative toxicological risk. Results of this study showed that Western juniper oil not toxic for D. magna and 0 . mykiss although toxic for $S$. copricornutum at $5.0 \mathrm{mg} / \mathrm{L}$. Besides that researcher reported that Port orford oil $E_{50}$ value (48 hour) for $D$. magna as 1.9 $\mathrm{mg} / \mathrm{L}$.

The purpose of Khalifa et al., (2011) study was to assess the antioxidant role of wheat germ oil (WGO) and grape seed oil (GSO) in chlorpyrifos-induced oxidative stress, biochemical and histological changes in liver in male albino rats. The results showed that the enzyme activities were significantly increased in rats administrated only by chlorpyrifos. Besides that Wheat germ oil and grape seed oil supplementation caused significant improvement in different biochemical parameters of all rat groups. Toxic effects of Wheat Germ and Grape Seed Oil on aquatic organisms are not available.

\section{REFERENCES}

Bakkali, F., Averbeck, S., Averbeck, D., Idaomar, M., 2008. Biological effects of essential Oils - a review. Food Chem. Toxicol. 46: 446-475. doi: 10.1016/j.fct.2007.09.106

Duringer, J.M., Swan, L.R., Walker, D.B., Craig, A.M., 2010. Acute aquatic toxicity of Western juniper (Juniperus occidentalis) foliage and Port Orford cedar (Chamaecyparis lawsoniana) heartwood oils. Environ Monit Assess. 170:585-598. doi: 10.1007/s10661-009-1259-0

Evandri, M.G., Battinelli, L., Daniele, C., Mastrangelo, S., Bolle, P., Mazzanti, G., 2005. The antimutagenic activity of Lavandula angustifolia (lavender) essential oil in the bacterial reverse mutation assay. Food and Chemical Toxicology. 43: 1381-1387. doi: 10.1016/j.fct.2005.03.013

Hajhashemi, V., Ghannadi, A., Sharif, B., 2003. Anti-inflammatory and analgesic properties of the leaf extracts and essential oil of Lavandula angustifolia Mill. J. Ethnopharmacol. 89, 67-71. doi:10.1016/S0378-8741(03)00234-4

Hammer, K.A., Carson, C.F., Riley, T.V., 1999. Antimicrobial activity of essential oils and other plant extracts. Journal of Applied Microbiology, 86(6): 985-990. doi: 10.1046/j.1365-2672.1999.00780.x

Hammer, K.A., Carson, C.F., Riley, T.V., 2006. A review of the toxicity of Melaleuca alternifolia (tea tree) oil. Nielsen Food and Chemical Toxicology, 44: 616-625. doi: 10.1016/j.fct.2005.09.001

Khalifa, F.K., Khalil, F.A., Barakat, H.A., Hassan, M.M., 2011. Protective Role of Wheat Germ and Grape Seed Oils in Chlorpyrifos-Induced Oxidative Stress, Biochemical and Histological Alterations in Liver of Rats Australian. Journal of Basic and Applied Sciences, 5(10): 54-66.

Khater, H.F., Hanafy, A., Abdel-Mageed, A.D., Ramadan, M.Y., El-Madawy R.S. 2011. Control of the myiasis-producing fly, Lucilia sericata with Egyptian essential oils. Inter. J. Dermatol. 50: 187-194. doi: 10.1111/j.1365-4632.2010.04656.x

Laborda, R., Manzanoa, I., Gamonb, M., Gavidiac, I., Perez-Bermudezc, P. Boludac, R., 2013. Effects of Rosmarinus officinalis and Salvia officinalis essential oils on Tetranychus urticae Koch (Acari: Tetranychidae) Industrial Crops and Products 48: 106-110.

Le Blanc, G.A., 1980. Acute toxicity of priority pollutants to water flea (Daphnia magna). Bull. Environ. Contam. Toxicol. 24: 684-691.
Our results and the results of the other related research studies showed that essential oils cause immobilization/mortality of daphnia at low concentrations. As with RO, TTO, WGO, GSO, TO and EO was determined according to Zucker's (1985) criteria that this chemical was slightly toxic for daphnia.

As it is well known that the effects of toxic chemicals on early developmental stages of aquatic organisms are of great importance in the protection of the natural population's health. This results bring us a conclusion that the essential oils has toxic effects on neonate and decreased mobilization percentage of exposed neonates became more important from the ecotoxicological point of view. Besides that considering the increasing use of this essential oils for personal care and another uses, their safety profile must be carefully determined.

Miresmailli, S., Bradbury, R., Isman, M.B., 2006. Comparative toxicity of Rosmarinus officinalis $L$. essential oil and blends of its major constituents against Tetranychus urticae Koch (Acari: Tetranychidae) on two different host plants. Pest Manag Sci 62:366-371. doi: 10.1002/ps.1157

OECD - Organization for Economic Cooperation and Development, 2004. Guideline for testing of chemicals. Daphnia sp., Acute Immobilisation Test OECD 202, Paris.

Özcan, M. M. and Arslan, D., 2011. Antioxidant effect of essential oils of rosemary, clove and cinnamon on hazelnut and poppy oils. Food Chemistry, 129:1, 171-174. doi: 10.1016/j.foodchem.2011.01.055

Park, H.M., Kim, J., Chang, K.S., Kim, B.S., Yang, Y.J., Kim, G.H., Shin, S.C., Park, I.K., 2011. Larvicidal activity of Myrtaceae essential oils and their components against Aedes aegypti, acute toxicity on Daphnia magna, and aqueous residue. J. Med. Entomol. 48: 405- 410 doi: 10.1603/ME10108

Parlak, H., Çakal Arslan, O., Boyacıoğlu, M., Karaslan, M.A., 2010. Acute and Chronic Toxicity of contaminated fresh water and sediment of Nif Brook on Daphnia magna (Straus, 1820). Ege J Fish Aqua Sci, 27 (4): 135-141.

Pavela, R., 2008. Insecticidal Properties of Several Essential Oils on the House Fly (Musca domestica L.) Phytother. Res. 22, 274-278. doi: $10.1002 / p t r .2300$

Pavela, R., 2014. Insecticidal properties of Pimpinella anisum essential oils against the Culex quinquefasciatus and the non-target organism Daphnia magna. Journal of Asia-Pacific Entomology 17: 287-293. doi: 10.1016/j.aspen.2014.02.001

Perry, N.S., Bollen, C., Perry, E.K., Ballard, C., 2003. Salvia for dementia therapy: review of pharmacological activity and pilot tolerability clinical trial. Pharmacol. Biochem. Behav. 75, 651-659.

Pimenta, A.S., Bayona, J.M., Garci'a, M.T., Solanas, A.M., 2000. Evaluation of Acute Toxicity and Genotoxicity of Liquid Products from Pyrolysis of Eucalyptus grandis Wood. Arch. Environ. Contam. Toxicol. 38: 169-175.

Reuveni, R., Fleischer, A., Putievski, E., 1984. Fungistatic activity of essential oils from Ocimum basilicum chemotypes. Phytopathol. Z. 10: 20-22.

Seo, S.M., Park, H.M., Park, I.K., 2012. Larvicidal activity of ajowan (Trachyspermum ammi) and Peru balsam (Myroxylon pereira) oils and 
blends of their constituents against mosquito, Aedes aegypti, acute toxicity on water flea, Daphnia magna, and aqueous residue. J. Agric Food Chem. 60: 5909-5914. doi: 10.1021/j301296d

Silva, J., Abebe, W., Sousa, S.M., Duarte, V.G., Machado, M.I.L., Matos F.J.A., 2003. Analgesic and anti-inflammatory effects of essential oils of Eucalyptus. J. Ethnopharmacol. 89, 277-283.

doi: 10.1590/S0102-695X2010000200007
Stroh, J., Wan, M.T., Isman, M.B., Moul, D.J., 1998. Evaluation of the acute toxicity to juvenile pacific coho salmon and rainbow trout of some plant essential oils, a formulated product, and the carrier. Bull. Environ. Contam. Toxicol. 60: 923-930.

Zucker, E., 1985. Hazard evaluation division, Standard evaluation procedure: Acute toxicity test for freshwater invertebrates. EPA/540/9-85/005 (p. 12). Washington: US Environmental Protection Agency. 